\title{
Transmission and protection in leprosy: indications of the role of mucosal immunity
}

\author{
P. RAMAPRASAD*, A. FERNANDO*, \\ S. MADHALE*, J. R. RAO*, V. K. EDWARD*, \\ P. D. SAMSON*, P. R. KLATSER $\dagger$, \\ M. Y. L. DE WIT $\dagger$, W. C. S. SMITH $\ddagger$, I. A. CREE $\S$ \\ * Stanley Browne Laboratories, Richardson Leprosy Hospital, \\ The Leprosy Mission, Miraj, MS, 416410 India \\ $\dagger$ Department of Biomedical Research, Royal Tropical Institute, \\ Meibergdreef, 11050 AZ Amsterdam, Netherlands \\ $\ddagger$ Department of Public Health, University of Aberdeen, Medical \\ School, Polwarth Building, Foresterhill, Aberdeen AB9 2ZD, \\ Scotland \\ $\S$ Department of Pathology, Institute of Ophthalmology, University \\ College London, Bath Street, London EC1V 9EL, England
}

Accepted for publication 14 August 1997

Summary Recent advances in treatment have achieved a large drop in the prevalence of active leprosy cases, but the incidence is at best decreasing slowly. Most people within leprosy-endemic populations have been exposed to Mycobacterium leprae, but few develop disease and it seems likely that the majority of the population develops protective immunity. If the site of initial infection is in the nose, dissemination of bacilli around the body to skin and nerve implies that the initial infection is bacillif erous and it has been shown that nasal M. leprae are detectable by polymerase chain reaction (PCR) of nasal swabs. Since salivary anti-M. leprae IgA (sMLIgA) levels are correlated with protection, ${ }^{5}$ we have surveyed groups of leprosy patients, contacts and the general population for both their SMLIgA and nasal PCR positivity. A total of 304 subjects were enrolled in the study: PCR and mucosal challenge tests were performed in 204 of these individuals. sMLIgA was present in $66 \%$ of treated patients, $76 \%$ of leprosy workers and $72 \%$ of healthy contacts. However, only $33 \%$ of indigenous subjects were $\mathrm{SMLIgA}+$, in contrast to the earlier studies showing $74 \%$ positivity. ${ }^{5} \mathrm{PCR}$ for $M$. leprae was present in both household contacts $(2 \%)$ and indigenous controls $(5 \%)$. In a subsequent follow-up study, nasal swabs were taken from 97 of those studied in the first series: three PCR + individuals followed up after one year became negative, while of the remaining 94 PCR - individuals retested, 2

Correspondence: Dr I. A. Cree, Department of Pathology, Institute of Ophthalmology, Bath Street, London EC1V 9EL. Tel: 0171-608-6808 Fax: 0171-608-6862 e-mail: i.cree@ucl.ac.uk 
became positive. Of 112 subjects retested with the mucosal challenge test for sMLIgA: 22 converted from positive to negative and 12 from negative to positive. These results suggest that there is widespread subclinical transmission of $M$. leprae with transient inf ection of the nose resulting in the development of a mucosal immune response, despite the fact that few individuals will develop clinical disease. This may explain the current lack of effect of multidrug therapy (MDT) control programmes on incidence, although the reduction in general population immunity is consistent with some effect of MDT on transmission.

\section{Introduction}

Despite the recent success of multiple drug therapy (MDT) in reducing the number of active cases of leprosy in the world to an estimated 1.3 million $^{1}$ from 12 to 15 million only 10 years ago, there are still about 8 million bacteriologically cured cases, many of whom suffer from disability as a result of their leprosy. Although prevalence has fallen, there is little evidence of an effect on incidence in the main endemic countries, even in those with good MDT-based control programmes. Since MDT is only given to those with clinically apparent disease, this suggests that there may be substantial subclinical transmission of Mycobacterium leprae infection to individuals within the population, the majority of whom will not develop overt disease. The occurrence of subclinical transmission is also suggested by the poor correlation between lepromatous (multibacillary) rates and overall leprosy prevalence: good correlation would be expected if lepromatous patients were largely responsible for spread of infection. A significant level of subclinical infection has considerable implications for the future success of the WHO's stated aim of eliminating leprosy as a public health problem, since transmission would not be controlled by current MDT-based control programmes.

Studies of leprosy transmission are hindered by the need to follow up contacts of leprosy patients for up to 10-15 years before new infection becomes clinically apparent. However, the recent development of sensitive polymerase chain reaction (PCR) methods for the detection of small numbers of $M$. leprae should enable infection rates to be determined. The sensitivity of PCR is limited to approximately 5 bacteria on the end of a nasal swab. ${ }^{2,3}$ PCR of nasal swabs cannot distinguish infection from nasal carriage, or live from dead bacteria. In the case of leprosy, infection is likely to mean penetration of the nasal mucosa-ENT examination of PCR positive cases is required to confirm this. Use of PCR technology by Klatser et al..$^{2,3}$ in Indonesia has indicated infection/nasal carriage of $M$. leprae in $5-8 \%$ of the general population. This is much higher that the prevalence rate of leprosy in the region, which is approximately $0 \cdot 1 \%$. While positive results due to environmental contamination of the nasal mucosa without active infection cannot be totally excluded, it is likely that a high proportion of these PCR+ individuals are infected, and that they will never develop clinical disease.

The high rate of nasal $M$. leprae PCR positivity adds weight to the hypothesis that initial infection by $M$. leprae occurs in the nose. ${ }^{4}$ Previous work has shown that prevalence of a salivary $\operatorname{IgA}$ response to $M$. leprae (MLIgA) is inversely related to risk of disease development. ${ }^{5}$ It seems likely that local mucosal immunity within the nose is the first line of defence against leprosy. We therefore developed a mucosal challenge test for nasal immunity to $M$. leprae and demonstrated anamnestic salivary IgA 
responses in people previously exposed to leprosy. ${ }^{6}$ This is in line with the hypothesis that widespread $M$. leprae infection within a population will result in protective immunity in most individuals, evidenced by a mucosal immune response. ${ }^{5}$ We anticipated that few individuals would be PCR positive at any one time, and that this would be transient, while recurrent exposure would lead to high rates of mucosal immunity to $M$. leprae. To test this, we have related the mucosal immune response to infection by combining measurements of the salivary IgA response to $M$. leprae with detection of nasal $M$. leprae by PCR to characterize the immune status of putative at risk and protected individuals within a leprosy endemic population. In addition we have performed serological studies to provide corroborating information on recent and past exposure to M. leprae.

\section{Materials and methods}

Most of the field and laboratory work described as part of this international collaborative study was performed in Miraj by the staff of the Richardson Leprosy Hospital. Audit and training were provided from the European centres.

\section{SUBJECTS}

A total of 304 subjects from four groups (healthy household contacts, treated patients, leprosy workers and indigenous controls with no history of leprosy contact) were recruited to the first clinical study. Of these individuals, 243 completed mucosal challenge tests, and 227 nasal swabs were tested for $M$. leprae by PCR: 204 had both tests. Subsequently, 133 were traced for the second follow-up study one year later. PCR was performed in 97 of these individuals and a mucosal challenge test in 112 subjects. The remainder in the initial and follow-up studies declined part or all of the investigations required. A detailed breakdown of the subject groups by age, sex and group is shown in Table 1. Leprosy patients were all either inpatients or outpatients of the Richardson Leprosy Hospital, Miraj. They were classified on the Ridley-Jopling scale by clinical and smear results as BT (10 cases), BB (1), BL (15) and LL (15). Two

Table 1. Age, sex and subject category information, together with the number in the study and the number retested

\begin{tabular}{|c|c|c|c|c|c|}
\hline Group & $\begin{array}{c}\text { Age } \\
\text { mean and range }\end{array}$ & $\begin{array}{l}\text { Sex } \\
\% \text { male }\end{array}$ & $\begin{array}{l}\text { Number in } \\
\text { study }\end{array}$ & $\begin{array}{l}\text { Number with } \\
\text { both tests }\end{array}$ & $\begin{array}{l}\text { Number } \\
\text { retested }\end{array}$ \\
\hline Indigenous subjects & $22(15-54)$ & 97 & 89 & 41 & 35 \\
\hline Healthy contacts & $28(15-60)$ & 39 & 134 & 95 & 73 \\
\hline Leprosy workers & $40(27-55)$ & 88 & 33 & 25 & 11 \\
\hline Patients (treated) & $43(13-82)$ & 81 & 48 & 43 & 14 \\
\hline ................Active* & $44(13-74)$ & 91 & 32 & 31 & 13 \\
\hline ................Inactive* & $49(21-82)$ & 58 & 12 & 12 & 1 \\
\hline All subjects & $30(13-82)$ & 66 & 304 & 204 & 133 \\
\hline
\end{tabular}

\footnotetext{
*Activity could not be determined in three patients due to insufficient information.
} 
remaining cases were thought to have polyneuritic leprosy on clinical grounds. Biopsy results were available for 2 cases. For analysis, paucibacillary patients were classified as active if they had received less than 6 months MDT or their last smear was positive. Multibacillary patients were classified as active if their last smear was positive or they had received less than 24 months treatment. On this basis, 32/44 assessable treated patients were classified as active cases. Healthy household contacts were identified by reference to patients of the same hospital's outpatient clinics. They were individuals living in the same house as a known previously treated leprosy patient who was therefore unlikely to be excreting bacilli. An additional group from the indigenous population was drawn from people of similar socioeconomic status living close to leprosy clinics thoughout the study area and known socially to the paramedical workers. Ethical clearance for the study was obtained from the Richardson Leprosy Hospital Ethics Committee, the Leprosy Mission, and Tayside Ethics Committee. All studies were conducted in accordance with the Helsinki declaration and informed consent obtained from the patients.

Each subject was asked to attend two clinic appointments. At the first appointment the procedures explained, a history and examination were performed and samples were taken. Nasal swabs (Medical Wire and Equipment Co, Corsham, UK) dipped in sterile saline were passed pernasally along the base of the inferior turbinate until it encountered the posterior wall of the nasopharynx. Swabs were cooled and transported to the laboratory the same day. A $10 \mathrm{ml}$ venous blood sample was taken and saliva obtained without stimulation by asking the subject to expel saliva over $5 \mathrm{~min}$ into a beaker. Finally, each subject was given an intranasal administration of $1 \mathrm{ml}$ of $0 \cdot 1 \mu \mathrm{g} / \mathrm{ml}$ leprosin A (Rees' skin test antigen, gift from Dr M. J. Colston, National Institute for Medical Research, London, UK) $0.5 \mathrm{ml}$ to each nostril with the head tilted back. ${ }^{6}$ Laboratory staff were present at each clinic appointment to collect the samples and complete records on each subject. At the second visit three days later, a history was taken to check that there were no side-effects of the leprosin A, and a further saliva sample was obtained.

\section{ELISA PROTOCOL FOR ANTI-M. LEPRAE IGA}

This was performed as previously described. ${ }^{5}$ Flat bottom Immulon 2 polystyrene plates (Dynatech Ltd, Billingshurst, UK) were coated with $0 \cdot 1 \%$ gelatin (Sigma Chemical Co Ltd, Poole, UK). For coating, $0.5 \mathrm{~g}$ gelatin was dissolved in $500 \mathrm{ml}$ distilled water and placed in a waterbath at $60^{\circ} \mathrm{C}$ for $1 \mathrm{~h}$. Plates were immersed in gelatin vertically twice and tapped on bench to remove bubbles, the solution was flicked off and the plates tapped on towels to remove excess. Following this, the plates were dried for $2 \mathrm{hr}$ at $60^{\circ} \mathrm{C}$ in a dry oven. Whole $M$. leprae in volatile ammonium acetate/carbonate buffer $\mathrm{pH} 8.0(50 \mu \mathrm{l}$ of $1 \times 10^{7}$ bacilli $/ \mathrm{ml}$ ) was added to each well in alternate columns of 3 wells (M. leprae wells) across the plates, which were then dried overnight at $37^{\circ} \mathrm{C}$ in dry oven. The remaining wells acted as negative control (No $M$. leprae) wells.

The ELISA was performed by blocking with $200 \mu$ l per well $3 \%$ bovine serum albumin (BSA, Sigma) in phosphate-buffered saline (PBS) $\mathrm{pH} 7 \cdot 4$ for $2 \mathrm{hr}$ at $37^{\circ} \mathrm{C}$, washing with PBS containing $0 \cdot 1 \%$ BSA 4 times over 15 min using a repeating pipette to remove any loosely adherent bacilli, and then adding $100 \mu \mathrm{l}$ test saliva or standard (pooled saliva) diluted 1 in 2,1 in 4,1 in 16 and 1 in 32 with PBS $+0 \cdot 1 \%$ BSA to test wells. Following saliva addition, the plates were incubated at $37^{\circ} \mathrm{C}$ for $120 \mathrm{~min}$ in 
humidified chamber and then washed 4 times over $15 \mathrm{~min}$ with PBS containing $0 \cdot 1 \%$ BSA using a repeating pipette. For detection of bound antibody, a volume of $100 \mu \mathrm{l}$ per well of optimally-diluted polyclonal affinity purified anti-IgA antibody conjugated to alkaline phosphatase (Sigma: 1:1000 for A3400; 1:2000 for A3063) was added across the plate. The conjugate was diluted in $50 \mathrm{~mm}$ Tris buffer $\mathrm{pH} 8.0$. The plates were then incubated at $37^{\circ} \mathrm{C}$ for $90 \mathrm{~min}$ and washed in $50 \mathrm{~mm}$ Tris buffer $\mathrm{pH} 8.0$ containing $0 \cdot 1 \%$ BSA over 15 min using a repeating pipette before addition of $100 \mu \mathrm{l}$ substrate to each well (Sigma; pNPP $1 \mathrm{mg} / \mathrm{ml}$ in DEA diethanolamine $\mathrm{pH} 9 \cdot 8$ ). Plates were incubated in the dark at room temperature for 15-20 min until the lowest standard was visible. The reaction was terminated by adding $25 \mu \mathrm{l} 2 \mathrm{~N} \mathrm{NaOH}$ and read using an automated Dynatech MR5000 ELISA reader $(410 \mathrm{~nm})$.

While we would have preferred to use a standard saliva to avoid the use of titres, the dilute nature of saliva made this impossible to construct. To obtain the true result for each test sample, the 'No $M$. leprae' control result was subtracted from the ' $M$. leprae' result.

\section{ELISA FOR TOTAL SALIVARY IGA}

Flat bottom Dynatech Immulon 2 polystyrene plates were coated with $100 \mu$ per well affinity purified anti-human $\mathrm{IgA}$ in carbonate buffer $\mathrm{pH} 9 \cdot 0$ and incubated overnight at $4^{\circ} \mathrm{C}$. The plates were then blocked with $200 \mu \mathrm{l}$ per well $2 \%$ milk protein in $50 \mathrm{~mm}$ carbonate buffer $\mathrm{pH} 9.0$ for $2 \mathrm{hr}$ at $37^{\circ} \mathrm{C}$, washed with PBS containing $0.1 \%$ milk protein and $0.05 \%$ Tween (PBS/TM) 4 times using a wash bottle, and $100 \mu$ l test saliva diluted 1 in 1000 with PBS/TM, or standard IgA (Sigma) in PBS/TM added and the plate incubated at $37^{\circ} \mathrm{C}$ for $120 \mathrm{~min}$ in humidified chamber. Following this, the plate was washed with PBS containing $0.05 \%$ Tween $(\mathrm{PBS} / \mathrm{T}) 4$ times using a wash bottle. Captured IgA was detected by adding $100 \mu$ l per well of optimally diluted (Sigma: 1:1000 for A3400; 1:2000 for A3063) polyclonal affinity purified anti-IgA antibody conjugated to alkaline phosphatase in $50 \mathrm{~mm}$ Tris buffer $\mathrm{pH} 8.0$ and incubating at $37^{\circ} \mathrm{C}$ for $90 \mathrm{~min}$. The plates were then washed with $50 \mathrm{~mm}$ Tris buffer $\mathrm{pH} 8.04$ times using a wash bottle and $100 \mu \mathrm{l}$ substrate added to each well (pNPP $1 \mathrm{mg} / \mathrm{ml}$ in DEA diethanolamine $\mathrm{pH} 9 \cdot 8$ ). The plates were incubated in the dark at room temperature for 15-20 min until lowest standard was visible and the reaction terminated by adding $25 \mu 12 \mathrm{~N}$ sodium hydroxide (Sigma). Plates were read in an automated Dynatech MR5000 ELISA reader $(410 \mathrm{~nm})$.

ELISA FOR ANTI-PGL1 ANTIBODIES (BSA GLYCOCONJUGATE WITH PGL1 DISACCHARIDE)

A glycoconjugate with bovine serum albumin which mimics the immunodominant epitope of the phenolic glycolipid coat of $M$. leprae (BSAC) was obtained from Dr M. J. Colston and used as before. ${ }^{7}$ BSAC was dissolved in PBS adjusted to $\mathrm{pH} 9.6$ with $4 \mathrm{~N} \mathrm{NaOH}$ at $2 \mu \mathrm{g} / \mathrm{ml}$ and adsorbed onto Immulon II plates (Dynatech) overnight at $37^{\circ} \mathrm{C}$ (humidified) using $100 \mu \mathrm{l}$ per well. Serum samples were thawed and prediluted $1: 100$ in sample dilution buffer (PBS $+0 \cdot 5 \%$ Tween $20+5 \%$ Normal Goat Serum) and stored at $4{ }^{\circ} \mathrm{C}$ overnight in plastic tubes. Standards were also made up in sample dilution buffer using pooled serum from 20 subjects with high absorbances in an initial screen at 
1:25 to 1:800 with a buffer only control. Coated plates were washed four times over $15 \mathrm{~min}$ in wash buffer (PBS $+0 \cdot 5 \%$ Tween $20+0 \cdot 1 \%$ BSA) and then incubated with $100 \mu \mathrm{l} /$ well of the prediluted test samples buffer for $90 \mathrm{~min}$ at $37^{\circ} \mathrm{C}$. The plates were washed a further four times over $15 \mathrm{~min}$ in wash buffer and the second antibody added $(100 \mu \mathrm{l} /$ well anti-Ig peroxidase conjugate, 1:2000 in wash buffer, Sigma) and incubated at $37^{\circ} \mathrm{C}$ for $90 \mathrm{~min}$. The plates were washed a further four times over $15 \mathrm{~min}$ in wash buffer and o-phenylenediamine (OPD, Sigma) substrate at $1 \mathrm{mg} / \mathrm{ml}$ with $1 \mu \mathrm{l} / \mathrm{ml} \mathrm{H}_{2} \mathrm{O}_{2}$ in CitratePhosphate buffer, $\mathrm{pH} 5 \cdot 0$. The citrate-phosphate buffer was made up with citric acid $(4.668 \mathrm{~g})$ and dibasic sodium phosphate $\left(\mathrm{Na}_{2} \mathrm{HPO}_{4} ; 7.299 \mathrm{~g}\right)$ in distilled water $(100 \mathrm{ml})$ and adjusted to $\mathrm{pH} 5.0$ with sodium hydroxide or hydrochloric acid. The plates were incubated at $37^{\circ} \mathrm{C}$ for $30 \mathrm{~min}$ and the reaction stopped with $2 \mathrm{~N}$ sulphuric acid. The plates were read in an automated Dynatech MR5000 ELISA reader at $490 \mathrm{~nm}$ and the results analysed using the standards to produce a reference curve (linear fit-arbitrary units [AU]).

\section{ELISA FOR ANTI-LIPOARABINOMANNAN ANTIBODIES}

Serum ELISAs for anti-lipoarabinomannan antibodies (LAM) were performed using LAM as antigen, coated directly overnight at $50 \mu \mathrm{l} /$ well $2 \mu \mathrm{g} / \mathrm{ml} \mathrm{LAM}$ in $30 \% \mathrm{PBS}, 70 \%$ Methanol onto Immulon II plates. LAM was obtained as a gift from Dr P. Brennan and Dr J. Bellisle, to whom we are most grateful. Following coating, the ELISA was performed in exactly the same way as the whole $M$. leprae ELISA, avoiding the use of Tween in washes.

\section{PCR DETECTION OF M. LEPRAE}

PCR detection of $M$. leprae was performed using the nested primer set S13/S62 resulting in amplification of a 531 base pair fragment of the $M$. leprae genome. ${ }^{2,8}$ Nasal swabs were frozen at $-30^{\circ} \mathrm{C}$ until extraction, which was performed by cutting the cotton end off the swab, placing it in lysis buffer and incubating at $60^{\circ} \mathrm{C}$ under paraffin oil for $18 \mathrm{hr}$ in a $1.5 \mathrm{ml}$ plastic tube (Nycomed), followed by $97^{\circ} \mathrm{C}$ for $15 \mathrm{~min}$. Lysis buffer was prepared from two stock solutions: (A) proteinase $\mathrm{K} 10 \mathrm{mg} / \mathrm{l}$ in $1 \mathrm{M}$ Tris- $\mathrm{HCl}, \mathrm{pH} 8.5$ and (B) $0.5 \%$ Tween 20 frozen in aliquots, and made up by adding $100 \mu \mathrm{l}$ of A and B with $800-\mu \mathrm{l}$ distilled water immediately before use.

The PCR reaction was performed using prepared vials containing $35 \mu \mathrm{l}$ PCR-mix, made up as $5 \mu \mathrm{l} 10 \times$ PCR buffer, $2 \mu \mathrm{l}$ dNTPs (1mM dATP, dCTP, dGTP, dUTP), $100 \mathrm{ng}$ primer S13, $100 \mathrm{ng}$ primer S62, $23 \mu \mathrm{l}$ distilled water, $5 \mu \mathrm{l}$ DMSO, 2.5 U Taq polymerase (Pharmacia) and 0.5 U Uracil-N-Glycosylase (UNG). Paraffin liquid (40 $\mu$ l) was placed on top of the mix and the vials frozen at $-20^{\circ} \mathrm{C}$. In early trials, frozen PCR mix vials were sent out from Amsterdam to Miraj in dry ice. $M$. leprae DNA stock solution $25 \mathrm{ng} / \mu \mathrm{l}$ was diluted in distilled water to provide 8 positive controls $(2.5 \mathrm{ng} / \mu \mathrm{l}$ to $8 \mathrm{fg} / \mu \mathrm{l})$ and test samples diluted 1:12.5 before use. Negative controls included distilled water (Amsterdam and local), and lysis buffer alone from the batch used for extraction. The PCR-mix vials were thawed immediately before use and placed on ice. To each vial was added $15 \mu$ l of extracted test, positive control, or negative control samples. PCR was performed in a Hybaid Omnigene machine with up to 48 wells in one run. UNG incubation was performed for $10 \mathrm{~min}$ at $25^{\circ} \mathrm{C}$, then $\mathrm{UNG}$ inactivation for $10 \mathrm{~min}$ at $95^{\circ} \mathrm{C}$, following by 35 cycles, each consisting of denaturation $\left(2 \mathrm{~min}\right.$ at $\left.94^{\circ} \mathrm{C}\right)$, annealing 
$\left(2 \mathrm{~min}\right.$ at $\left.60^{\circ} \mathrm{C}\right)$, and elongation $\left(3 \mathrm{~min}\right.$ at $\left.72^{\circ} \mathrm{C}\right)$. Following PCR amplification, samples were either tested on a $2 \%$ agarose gel immediately or stored at $-20^{\circ} \mathrm{C}$ pending analysis. Positive samples showed a band at $531 \mathrm{bp}$.

Confirmation of positive samples was performed by gel electrophoresis and hybridization of the amplified product with digoxigenin-NBT-BCIP detection. ${ }^{2}$ Negative samples were checked for PCR inhibition activity by the addition of an artificial template. Positive samples were retested in Amsterdam and confirmed if found positive on retesting. To avoid laboratory contamination, sample preparation, mix preparation/storage, sample addition, and PCR/sample analysis were physically separated by performing each step in separate rooms with individually air conditioned and filtered air. Each room contained separate glove boxes and pipettes allowing complete separation of each stage.

ANALYSIS OF RESULTS

Clinical and laboratory data were collected and analysed in an Access (Microsoft) database. Criteria of positivity for the ELISA and PCR assays were as follows:

- Salivary anti-M. leprae IgA (sMLIgA): Positive = antibody titre of 2 or more over negative control wells.

- Salivary anti-LAM IgA (sIgALAM): Positive=antibody titre of 4 or more over negative control wells.

- Total salivary IgA: Measurements were related to standards of purified IgA (Sigma) allowing expression of the results as $\mathrm{mg} / \mathrm{ml}$.

- Serum anti-M. leprae $\operatorname{IgA}(\mathrm{MLIgA})$ : Positive = antibody titre of 25 or more over negative control wells.

- Serum anti-M. leprae $\operatorname{IgG}(\mathrm{MLIgG})$ : Positive= antibody titre of 50 or more over negative control wells.

- Serum anti-LAM IgG and IgM: Positive=antibody titre of 100 or more over negative control wells.

- Serum anti-BSAC (glycojugate ELISA) IgG, IgM and IgA: Positive $=100$ or more arbitrary units (AU) defined by reference to a pooled serum standard constructed by pooling sera from 20 lepromatous patients. Results are given in arbitrary units and a figure of $>100 \mathrm{AU}$ was accepted as a positive result.

Statistical analysis was performed on grouped data by the $\chi$-squared test and on normally distributed datasets by Student's $t$-test.

\section{Results}

The results of the ELISA and PCR measurements are shown in Table 2 for each group of subjects tested. Comparisons between salivary anti- $M$. leprae IgA and the two most robust markers of infection, PCR and serum IgM anti-BSAC are shown in Table 3. The results of retesting after an interval of one year are shown in Table 4.

RESULTS FOR ANTI- $M$. LEPRAE SALIVARY IGA (SMLigA), TOTAL IGA, AND ANTI-LAM

There was an overall sMLIgA positivity rate of $62 \%$, a figure which is similar to the $72 \%$ 
Table 2. Results of salivary and serum ELISAs for antibodies against $M$. leprae and M. leprae antigens compared with PCR for $M$. leprae for each group tested

\begin{tabular}{|c|c|c|c|c|c|c|}
\hline Group & $\begin{array}{c}\text { sMLIgA+ } \\
(\%) \\
\text { Mean range }\end{array}$ & $\begin{array}{c}\text { sIgALAM+ } \\
(\%) \\
\text { Mean range }\end{array}$ & $\begin{array}{c}\text { MLIgA+ } \\
(\%) \\
\text { Mean range }\end{array}$ & $\begin{array}{c}\text { MLIgG+ } \\
(\%) \\
\text { Mean range }\end{array}$ & $\begin{array}{c}\text { IgG-LAM } \\
(\%) \\
\text { Mean range }\end{array}$ & $\begin{array}{c}\text { IgM-LAM } \\
(\%) \\
\text { Mean range }\end{array}$ \\
\hline $\begin{array}{l}\text { Indigenous } \\
\text { subjects }\end{array}$ & $\begin{array}{c}19 / 58 \\
(33 \%) \\
2 \cdot 4 \\
(0-64)\end{array}$ & $\begin{array}{c}7 / 40 \\
(18 \%) \\
0 \cdot 7 \\
(0-8)\end{array}$ & $\begin{array}{c}13 / 59 \\
(22 \%) \\
31 \cdot 0 \\
(0-200)\end{array}$ & $\begin{array}{c}35 / 62 \\
(56 \%) \\
296 \cdot 6 \\
(0-600)\end{array}$ & $\begin{array}{c}31 / 50 \\
(62 \%) \\
133 \cdot 0 \\
(25-200)\end{array}$ & $\begin{array}{c}17 / 51 \\
(33 \%) \\
161 \cdot 8 \\
(25-800)\end{array}$ \\
\hline $\begin{array}{l}\text { Healthy } \\
\text { contacts }\end{array}$ & $\begin{array}{c}83 / 116 \\
(72 \%) \\
4 \cdot 4 \\
(0-64)\end{array}$ & $\begin{array}{c}46 / 118 \\
(39 \%) \\
1 \cdot 2 \\
(0-8)\end{array}$ & $\begin{array}{c}44 / 90 \\
(49 \%) \\
42 \cdot 7 \\
(0-200)\end{array}$ & $\begin{array}{c}26 / 111 \\
(23 \%) \\
142 \cdot 5 \\
(0-1200)\end{array}$ & $\begin{array}{c}42 / 100 \\
(42 \%) \\
105 \cdot 8 \\
(25-200)\end{array}$ & $\begin{array}{c}5 / 69 \\
(7 \%) \\
65 \cdot 9 \\
(25-200)\end{array}$ \\
\hline $\begin{array}{l}\text { Leprosy } \\
\text { workers }\end{array}$ & $\begin{array}{c}19 / 25 \\
(76 \%) \\
8 \cdot 4 \\
(0-64)\end{array}$ & $\begin{array}{c}16 / 26 \\
(62 \%) \\
3 \cdot 4 \\
(0-32)\end{array}$ & $\begin{array}{c}16 / 29 \\
(55 \%) \\
47 \cdot 7 \\
(0-250)\end{array}$ & $\begin{array}{c}24 / 30 \\
(80 \%) \\
462 \cdot 9 \\
(0-900)\end{array}$ & $\begin{array}{c}12 / 24 \\
(50 \%) \\
112 \cdot 9 \\
(25-200)\end{array}$ & $\begin{array}{c}8 / 25 \\
(32 \%) \\
129 \cdot 8 \\
(25-200)\end{array}$ \\
\hline Patients & $\begin{array}{c}29 / 44 \\
(66 \%) \\
3 \cdot 1 \\
(0-16)\end{array}$ & $\begin{array}{c}12 / 40 \\
(30 \%) \\
1 \cdot 5 \\
(0-16)\end{array}$ & $\begin{array}{c}23 / 35 \\
(54 \%) \\
55 \cdot 6 \\
(0-250)\end{array}$ & $\begin{array}{c}21 / 43 \\
(49 \%) \\
248 \cdot 9 \\
(0-600)\end{array}$ & $\begin{array}{c}13 / 44 \\
(29 \%) \\
84 \cdot 2 \\
(25-200)\end{array}$ & $\begin{array}{c}7 / 40 \\
(18 \%) \\
102 \cdot 1 \\
(25-800)\end{array}$ \\
\hline ...Active & $\begin{array}{c}24 / 32 \\
(75 \%) \\
3 \cdot 0 \\
(0-32)\end{array}$ & $\begin{array}{c}10 / 31 \\
(32 \%) \\
1 \cdot 8 \\
(0-16)\end{array}$ & $\begin{array}{c}18 / 27 \\
(67 \%) \\
55 \cdot 6 \\
(0-200)\end{array}$ & $\begin{array}{c}17 / 31 \\
(55 \%) \\
261 \cdot 3 \\
(0-600)\end{array}$ & $\begin{array}{c}10 / 32 \\
(31 \%) \\
88 \cdot 6 \\
(25-200)\end{array}$ & $\begin{array}{c}4 / 30 \\
(13 \%) \\
113 \cdot 0 \\
(25-800)\end{array}$ \\
\hline ...Inactive & $\begin{array}{c}5 / 12 \\
(42 \%) \\
2 \cdot 4 \\
(0-16)\end{array}$ & $\begin{array}{c}2 / 9 \\
(22 \%) \\
1 \cdot 0 \\
(0-8)\end{array}$ & $\begin{array}{c}5 / 8 \\
(63 \%) \\
50 \cdot 2 \\
(0-200)\end{array}$ & $\begin{array}{c}4 / 12 \\
(33 \%) \\
200 \cdot 0 \\
(0-600)\end{array}$ & $\begin{array}{c}3 / 12 \\
(25 \%) \\
82 \cdot 9 \\
(25-200)\end{array}$ & $\begin{array}{c}3 / 10 \\
(30 \%) \\
79 \cdot 2 \\
(25-150)\end{array}$ \\
\hline All subjects & $\begin{array}{c}150 / 243 \\
(62 \%) \\
4 \cdot 1 \\
(0-64)\end{array}$ & $\begin{array}{c}81 / 224 \\
(36 \%) \\
1 \cdot 5 \\
(0-32)\end{array}$ & $\begin{array}{c}96 / 213 \\
(45 \%) \\
45 \cdot 5 \\
(0-250)\end{array}$ & $\begin{array}{c}106 / 226 \\
(47 \%) \\
286 \cdot 2 \\
(0-1200)\end{array}$ & $\begin{array}{c}98 / 218 \\
(45 \%) \\
108 \cdot 9 \\
(25-200)\end{array}$ & $\begin{array}{c}37 / 185 \\
(20 \%) \\
103 \cdot 9 \\
(25-800)\end{array}$ \\
\hline
\end{tabular}

sMLIgA = salivary IgA anti-whole $M$. leprae, $\operatorname{sIgALAM}=$ salivary $\operatorname{IgA}$ anti-lipoarabinomannan, MLIgA = serum IgA anti-whole $M$. leprae, $\mathrm{MLIgG}=$ serum IgG anti-whole $M$. leprae, IgG-LAM=serum IgG anti-lipoarabinomannan, IgM-LAM = serum IgM anti-lipoarabinomannan, BSAC-IgG $=\operatorname{IgG}$ anti BSA-C, BSAC-IgM = IgM anti BSA-C, BSAC-IgA = IgA anti BSA-C, PCR = polymerase chain reaction.

positivity found during previous studies in both Bangladesh and Fiji. ${ }^{5}$ While most groups' sMLIgA rates are similar (healthy contacts $72 \%$, leprosy workers $76 \%$, patients $66 \%$ ), the low level of sMLIgA positivity (33\%) in the small group of subjects taken from the general population is striking (Table 2). As expected, sMLIgA rates were similarly high amongst healthy contacts, leprosy workers and treated patients (Table 2). There was considerable physiological variation in the concentration of $\operatorname{IgA}$ actually present in the saliva, ranging from 2 to $250 \mathrm{mg} / \mathrm{ml}$ with a mean of $49 \mathrm{mg} / \mathrm{ml}$. While there was no significant difference in salivary $\operatorname{IgA}$ concentration between subject categories, those found to be negative for SMLIgA were more likely to have a low total salivary IgA (mean $42 \mathrm{mg} / \mathrm{ml}$, sd $35 \mathrm{mg} / \mathrm{ml}$ ) than those with sMLIgA titres $>2$ (mean $59 \mathrm{mg} / \mathrm{ml}$, sd $49 \mathrm{mg} / \mathrm{ml})(t$-test, $p<0 \cdot 005)$, consistent with reduced sensitivity of the sMLIgA ELISA due to low IgA secretion or dilution by increased salivary flow. Antibodies to LAM have 
Table 2 (Continued)

\begin{tabular}{|c|c|c|c|c|}
\hline Group & $\begin{array}{c}\text { BSAC-IgG } \\
(\%) \\
\text { Mean range }\end{array}$ & $\begin{array}{c}\text { BSAC-IgM } \\
(\%) \\
\text { Mean range }\end{array}$ & $\begin{array}{c}\text { BSAC-IgA } \\
(\%) \\
\text { Mean range }\end{array}$ & $\begin{array}{c}\text { PCR+ } \\
(\%) \\
\text { Mean range }\end{array}$ \\
\hline $\begin{array}{l}\text { Indigenous } \\
\text { subjects }\end{array}$ & $\begin{array}{c}18 / 60 \\
(30 \%) \\
96 \\
(0-654)\end{array}$ & $\begin{array}{c}4 / 55 \\
(7 \%) \\
25 \\
(0-130)\end{array}$ & $\begin{array}{c}1 / 55 \\
(2 \%) \\
21 \\
(0-117)\end{array}$ & $\begin{array}{l}2 / 43 \\
(5 \%)\end{array}$ \\
\hline $\begin{array}{l}\text { Healthy } \\
\text { contacts }\end{array}$ & $\begin{array}{c}19 / 111 \\
(17 \%) \\
62 \\
(0-293)\end{array}$ & $\begin{array}{c}9 / 118 \\
(8 \%) \\
40 \\
(0-198)\end{array}$ & $\begin{array}{c}4 / 116 \\
(3 \%) \\
29 \\
(0-434)\end{array}$ & $\begin{array}{l}2 / 106 \\
(2 \%)\end{array}$ \\
\hline $\begin{array}{l}\text { Leprosy } \\
\text { workers }\end{array}$ & $\begin{array}{c}6 / 24 \\
(25 \%) \\
64 \\
(0-211)\end{array}$ & $\begin{array}{c}0 / 24 \\
(0 \%) \\
14 \\
(0-82)\end{array}$ & $\begin{array}{c}1 / 24 \\
(4 \%) \\
25 \\
(0-106)\end{array}$ & $\begin{array}{c}5 / 31 \\
(16 \%)\end{array}$ \\
\hline $\begin{array}{l}\text { Patients } \\
\text { (treated) }\end{array}$ & $\begin{array}{c}27 / 43 \\
(63 \%) \\
213 \\
(0-597)\end{array}$ & $\begin{array}{c}16 / 44 \\
(36 \%) \\
93 \\
(0-309)\end{array}$ & $\begin{array}{c}25 / 44 \\
(57 \%) \\
224 \\
(0-1074)\end{array}$ & $\begin{array}{l}4 / 44 \\
(9 \%)\end{array}$ \\
\hline ...Active & $\begin{array}{c}20 / 31 \\
(65 \%) \\
231 \\
(0-597)\end{array}$ & $\begin{array}{c}13 / 32 \\
(41 \%) \\
95 \\
(0-300)\end{array}$ & $\begin{array}{c}18 / 32 \\
(56 \%) \\
252 \\
(0-1074)\end{array}$ & $\begin{array}{l}2 / 32 \\
(6 \%)\end{array}$ \\
\hline ...Inactive & $\begin{array}{c}7 / 12 \\
(58 \%) \\
164 \\
(0-481)\end{array}$ & $\begin{array}{c}3 / 12 \\
(25 \%) \\
61 \\
(0-151)\end{array}$ & $\begin{array}{c}7 / 12 \\
(58 \%) \\
148 \\
(31-471)\end{array}$ & $\begin{array}{c}2 / 12 \\
(17 \%)\end{array}$ \\
\hline $\begin{array}{l}\text { All } \\
\text { subjects }\end{array}$ & $\begin{array}{c}70 / 238 \\
(29 \%) \\
98 \\
(0-654)\end{array}$ & $\begin{array}{c}29 / 241 \\
(12 \%) \\
44 \\
(0-310)\end{array}$ & $\begin{array}{c}31 / 239 \\
(13 \%) \\
63 \\
(0-1074)\end{array}$ & $\begin{array}{c}13 / 227 \\
(6 \%)\end{array}$ \\
\hline
\end{tabular}

previously been found in saliva ${ }^{9}$ and we have extended this work in the current study. The results show that $34 \%$ of all sMLIgA+ subjects were also sIgALAM positive while only $18 \%$ of the sMLIgA - subjects were positive for $\operatorname{sIgALAM}\left(\chi^{2}\right.$ test, $\left.p<0.0001\right)$, showing that a salivary anti-LAM response occurs in many of those with salivary IgA responses to whole $M$. leprae. In the indigenous subject group, only $18 \%$ of the subjects showed an $\operatorname{IgA}$ anti-LAM response in contrast to $39 \%$ of healthy contacts, $62 \%$ of leprosy workers and $30 \%$ of patients.

\section{PCR RESULTS}

PCR positivity rates (Table 2) were also in keeping with previously reported data. ${ }^{2,3}$ In contrast to the immunity rate, the $\mathrm{PCR}+$ rate was not reduced in subjects drawn from the general population in comparison with previous studies. The high numbers of PCR+ results amongst leprosy workers probably reflects environmental contamination of nasal secretions rather than infection, as discussed below. Of the PCR+ patients, 2 were treated for $<1$ year: all were multibacillary. 
Table 3. Comparison of ELISA for IgA antibodies to whole $M$. leprae (sMLIgA) with (a) nasal PCR for $M$. leprae, and (b) IgM anti-BSAC antibody positivity. Subjects with incomplete PCR or ELISA and/or mucosal testing were excluded from analysis

(a)

\begin{tabular}{|c|c|c|c|c|c|}
\hline Subject category & $\begin{array}{c}\text { PCR- } \\
\text { sMLIgA- }\end{array}$ & $\begin{array}{c}\text { PCR+ } \\
\text { sMLIgA- }\end{array}$ & $\begin{array}{c}\text { PCR+ } \\
\text { sMLIgA+ }\end{array}$ & $\begin{array}{c}\text { PCR- } \\
\text { sMLIgA+ }\end{array}$ & Total \\
\hline Indigenous subjects & 27 & 2 & 0 & 12 & 41 \\
\hline Healthy contacts & 27 & 0 & 2 & 66 & 95 \\
\hline Leprosy workers & 3 & 3 & 2 & 17 & 25 \\
\hline Patients (treated) & 13 & 2 & 2 & 26 & 43 \\
\hline All subjects & 70 & 7 & 6 & 121 & 204 \\
\hline
\end{tabular}

(b)

\begin{tabular}{lcccrr}
\hline Subject category & $\begin{array}{c}\text { sMLIgA- } \\
\text { BSAC- }\end{array}$ & $\begin{array}{c}\text { sMLIgA- } \\
\text { BSAC+ }\end{array}$ & $\begin{array}{c}\text { sMLIgA+ } \\
\text { BSAC+ }\end{array}$ & $\begin{array}{c}\text { sMLIgA+ } \\
\text { BSAC- }\end{array}$ & $\begin{array}{r}\text { Total } \\
\text { Indigenous subjects }\end{array}$ \\
Healthy contacts & 34 & 3 & 1 & 17 & 55 \\
Leprosy workers & 30 & 2 & 5 & 0 & 13 \\
Patients (treated) & 6 & 4 & 12 & 17 & 24 \\
All subjects & 81 & 9 & 18 & 125 & 44 \\
& & & & 233 \\
\hline
\end{tabular}

RESULTS OF SERUM ELISAS FOR WHOLE $M$. LEPRAE, LAM AND PGLI (BSAC)

ELISAs to whole $M$. leprae using whole serum are often unreliable, and it is also likely that there is cross-reaction between serum $M$. leprae antibodies and those directed against other mycobacteria. ${ }^{7}$ Nevertheless, it is interesting to note that the differences between group positivity rates for serum anti-M. leprae $\operatorname{IgA}(\mathrm{MLIgA})$ are similar to those for IgA in saliva with few indigenous subjects (22\%) showing positivity (Table 2$)$. Sera were regarded as anti-LAM positive if the titre was $>1: 100$. Since this test also lacks specificity and can be compromised by cross-reacting antibodies to other mycobacteria, it is probable that the levels of positivity are high in comparison with the true level of $M$. leprae exposure. BSAC represents a highly specific immunodominant epitope of PGL1, the outer cell wall lipid unique to M. leprae. IgM antibodies to PGL1 have previously been used as markers of recent infection ${ }^{10,11}$ and to follow the outcome of treatment. ${ }^{12-14}$ Small numbers of BSAC-IgM positive subjects (Table 2) were found in the indigenous subject and healthy contact groups, consistent with the PCR results suggesting small numbers of subclinically infected individuals in these groups. However, none of the leprosy workers were BSAC-IgM positive, suggesting that they were not infected and that the PCR positives in this group may be due to environmental nasal contamination of the subjects from hospital dust. Only two PCR positive individuals were IgM-BSAC+, the remainder being negative. This suggests that PCR positivity may precede PGLl/BSAC positivity, as might be expected from the pathogenesis of leprosy postulated at the start of this study. Since most of the patients tested were still under treatment (Table 1), their higher serological positivity than the other groups (Table 2) is expected. 
Table 4. Results of (a) sMLIgA $(n=126)$ and PCR $(n=100)$ retesting one year following initial test, and (b) BSAC $\operatorname{IgM}(n=86)$ and $\operatorname{IgG}(n=85)$ antibody status one year later showing the number changing their status from positive to negative $(+\gg-)$ and negative to positive $(-\gg+)$

\begin{tabular}{lcccc}
\hline (a) & sMLIgA $+\gg-$ & sMLIgA $-\gg+$ & PCR $+\gg-$ & PCR $-\gg+$ \\
\hline Indigenous subjects & $7 / 13$ & $7 / 17$ & $0 / 0$ & $3 / 19$ \\
Healthy contacts & $19 / 52$ & $13 / 19$ & $1 / 1$ & $3 / 55$ \\
Leprosy workers & $0 / 10$ & $0 / 1$ & $0 / 0$ & $0 / 10$ \\
Patients (treated) & $1 / 10$ & $2 / 4$ & $2 / 2$ & $1 / 13$ \\
All subjects & $27 / 85$ & $22 / 41$ & $3 / 3$ & $7 / 97$ \\
\end{tabular}

\begin{tabular}{lcccc}
\hline (b) & $\begin{array}{c}\text { BSAC-IgM } \\
+\gg-\end{array}$ & $\begin{array}{c}\text { BSAC-IgM } \\
-\gg+\end{array}$ & $\begin{array}{c}\text { BSAC-IgG } \\
+\gg-\end{array}$ & $\begin{array}{c}\text { BSAC-IgG } \\
-\gg+\end{array}$ \\
\hline Indigenous subjects & $0 / 1$ & $0 / 21$ & $2 / 3$ & $0 / 6$ \\
Healthy contacts & $2 / 2$ & $1 / 42$ & $8 / 12$ & $3 / 43$ \\
Leprosy workers & $0 / 0$ & $0 / 8$ & $3 / 4$ & $0 / 4$ \\
Patients (treated) & $0 / 5$ & $0 / 7$ & $4 / 7$ & $0 / 6$ \\
All subjects & $2 / 8$ & $1 / 78$ & $17 / 26$ & $3 / 59$ \\
\hline
\end{tabular}

\section{COMPARISON OF SERUM IGM ANTI-BSA-C AND PCR RESULTS WITH SALIVARY IGA}

ANTI-M. LEPRAE

Comparison of the PCR and sMLIgA ELISA results (Table 3) shows considerable differences between the subject groups ( $\chi^{2}$ test, all groups, $\left.p<0 \cdot 0001\right)$. Low numbers of subjects showed both SMLIgA and PCR positivity (3\%). Many subjects were negative for both sMLIgA and PCR (34\%), with most occurring in the control subject group; $66 \%$ were negative for both tests. PCR-/sMLIgA+ individuals were common in the healthy contact, leprosy worker, and treated patient groups, and least frequent in the general population group. PCR $+/ \mathrm{sMLIgA}-$ subjects were rare in all groups.

Comparison of the IgM-BSAC results with the salivary IgA results yields a similar pattern to that seen with PCR, with marked differences between groups $\left(\chi^{2}\right.$ test, $p<0.0001)$. Relatively few subjects are IgM-BSAC+/sMLIgA - or IgM-BSAC+/ sMLIgA+ (putative active infection). The highest proportion of IgM-BSAC-/sMLIgA(putative non-immune and non-exposed) individuals is in the indigenous subject group $(62 \%)$, just as found using PCR, whereas only $25-27 \%$ of those in the other groups fall into this category.

\section{RESULTS OF RETESTING}

Retesting was performed one year after the initial screen. A number of subjects declined part of the test (usually the blood sample) or failed to return on day 3 as asked. However, it was possible to determine the change in status of approximately half of the subjects in each group (sMLIgA $51 \%$, PCR 44\%), as shown in Table 4. sMLIgA status changed from positive to negative in $32 \%$ of subjects and from negative to positive in $54 \%$ of subjects. Considerable variation in sMLIgA positivity is expected given the variable concentration of $\operatorname{IgA}$ in saliva and the relatively low sensitivity of the whole M. leprae 
ELISA method. However, the number changing from sMLIgA - to sMLIgA + is clearly greater than the reverse, suggesting that there is conversion in at least $20 \%$ of nonimmune subjects over the year $\left(\chi^{2}\right.$ test, all subjects, $\left.p<0.001\right)$. Some of those changing from sMLIgA + to sMLIgA - may represent loss of immunity. This could be transient as the result of intercurrent infection and further follow-up studies would be usef ul. Of those who converted from PCR - to PCR+, 3 were sMLIgA+ and 4 sMLIgA-. The numbers are too small for statistical analysis. However, the PCR results confirm that PCR positivity is transient and can change within a year. Fewer subjects showed BSAC-IgM or BSAC-IgG conversion, but again this supports the presence of continuing transmission particularly within the healthy contact group.

\section{Discussion}

The numbers of PCR+ and sMLIgA+ individuals in each group are within expected limits based on previous PCR and IgA surveys, with exception of the indigenous control group which shows a strikingly low level of IgA positivity in comparison with the other groups, despite showing a similar PCR positivity rate to that found in Indonesia. ${ }^{3}$ Although in this study the indigenous control group had a preponderance of males, there was no evidence in any of the other groups of a sex or age-related difference in immunological parameters. The explanation for the low sMLIgA positivity in the indigenous population may lie in the rapidly increasing prosperity of this part of Maharashtra, but could also be due to the impact of some 14 years of aggressive casefinding and MDT treatment on transmission of the disease and hence on immunity rates. Further studies of the general population are needed to confirm this finding, since the sMLIgA results suggest that MDT programmes may reduce transmission sufficiently to reduce population immunity, but not to the point where subclinical infection (PCR positivity) disappears.

The sMLIgA response figures are low for a protective immune response which is apparently effective in most $(>90 \%)$ of the population. This may be explained by poor sensitivity of the ELISA and the prevalence of individuals with low salivary $\operatorname{IgA}$ secretion. However, it may also represent the limited utility of the salivary anti-M. leprae IgA response as a marker for protection, which may be due mainly to local cell-mediated responses within the nose. ${ }^{5}$ Such responses are difficult to study adequately: lymphocytes were not found in nasal washings with sufficient frequency to permit immunophenotyping (data not shown). We were unable to produce any better results that the previous Western blotting approach to analysis of salivary $\operatorname{IgA}$ responses. ${ }^{9}$ As before, there was no demonstrable salivary response to PGL1. As predicted from previous work, ${ }^{9}$ many of those found to be sMLIgA+ also had salivary IgA responses to LAM. There were relatively few salivary IgA anti-LAM responses amongst indigenous control subjects in comparison with the other groups tested. This provides further support for the observation that relatively few of the indigenous subject group showed salivary $\operatorname{IgA}$ responses to $M$. leprae antigens in comparison with the other groups tested.

$\mathrm{PCR}+$ individuals were found in both household contacts and indigenous controls, suggesting that bacilliferous nasal lesions occur without clinical disease. In follow-up studies, all those PCR + individuals who were re-examined were negative. This corroborates evidence from Indonesia ${ }^{3}$ showing transient subclinical nasal infection. As 
expected, some patients under treatment were positive. The leprosy workers' PCR results were not a great surprise considering the ability of leprosy patients to secrete large amounts of bacilli from the nose. ${ }^{15}$ Dead bacteria still contain DNA and it is likely that, dead or alive, $M$. leprae in hospital dust was responsible for this finding. However, a formal study of $M$. leprae in the environment is required and PCR is likely to prove a useful method for this purpose. Our contention that the PCR positive results amongst leprosy workers represent nasal contamination rather than infection is strengthened by the finding of low serum IgM antibody levels to PGL1 in these individuals since this is associated with active infection. ${ }^{10-14}$ Leprosy workers are at low risk of disease despite virtually continuous exposure to leprosy bacilli, which may be responsible for the $25 \%$ prevalence of serum IgG to BSA-C found in this study. In contrast to IgM responses, IgG responses to PGL1 (BSA-C) appear to be much more long-lasting. ${ }^{12}$ Nasal examination of those with PCR positivity is required to establish whether they have nasal lesions, and we hope to undertake this shortly. We agree with Hatta et al. ${ }^{3}$ that there may be subclinical transmission from those with transient bacilliferous nasal lesions to non-protected individuals.

Serum serology for whole $M$. leprae is unreliable for diagnosis, ${ }^{7,17,18}$ although it is notable that in this study the serum IgA data are generally similar to the salivary IgA data. The LAM used was derived from a fast-growing mycobacterial species and our results probably suffer from cross-reaction with serum antibodies to other mycobacteria. ${ }^{16}$ However, IgM antibodies to the immunodominant epitope of PGL1 (BSAC, a glycoconjugate of BSA) show results remarkably similar to the PCR results. There were too few PCR+ individuals retested to be sure of the relationship between PCR and PGL1 serology, but in other work it has been shown that there is no direct correlation. ${ }^{3,17}$ There may of course be a temporal relationship, and it would be worth looking to see if IgM anti-PGL1 antibodies appear after PCR positivity has resolved as part of a larger study. These results raise the possibility that PGL1 serology may prove useful for the detection of sub-clinical clusters of infection, as suggested by Baumgart et al. ${ }^{19}$ Since ELISA technology is much more easily applicable than PCR in the field, this finding is of considerable importance.

It appears that sMLIgA positivity and PCR positivity (presumed infection) are not mutually exclusive. Since first infection is likely to be followed by immunity in most individuals, it seems likely that those not yet infected (PCR-/sMLIgA-) will become transiently $\mathrm{PCR}+/ \mathrm{sMLIgA}$ - during primary infection and then develop immunity while infection resolves $(\mathrm{PCR}+/ \mathrm{sMLIgA}+)$. The results are broadly in line with this hypothesis. PCR+/sMLIgA+ individuals may be engaged in a successful defence against recent infection, and we have pursued this by retesting them one year after their previous test results when they would be expected to be PCR-/sMLIgA+ (putative protected). It is also possible that some of those thought to be immune (PCR-/sMLIgA+) could revert to the non-immune, non-infected state. Unfortunately, the numbers of individuals retested in these groups was too small in this study to be sure and larger studies are required. Our results indicate that more individuals convert from sMLIgA- to sMLIgA + than vice versa, consistent with a general gain in salivary mucosal immunity within the population reflecting continuing exposure of naive individuals to $M$. leprae. In populations with high exposure to $M$. leprae, most individuals would be expected to be those who are immune, with a proportion of non-immune individuals. Those with putative infection and either no immunity or developing immunity would be expected to 
be smaller groups, as indeed they are. However there were very few PCR+/sMLIgAindividuals, suggesting that the sMLIgA response develops relatively soon after inf ection in most individuals.

In conclusion, this study corroborates previous work from Indonesia ${ }^{2,3}$ which is consistent with widespread subclinical transmission of $M$. leprae producing transient nasal infection and the development of a mucosal immune response which may be protective. Subclinical transmission may explain the current lack of effect of MDT control programmes on incidence, although if confirmed in larger studies, the reduction in general population immunity is consistent with some effect of MDT on transmission.

\section{Acknowledgments}

We wish to thank Dr W. Terpstra, Dr P. J. Brennan, Dr J. T. Bellisle, Dr J. Colston, Dr C. Walter, Dr N. K. Mehra, Dr I. Nath, Dr S. Chiplunkar, Dr M. G. Deo, Dr M. MacDonald and the staff of the Richardson Leprosy Hospital for their assistance. We are grateful to the Commission of the European Communities, Directorate General XII for Science, Research and Development (TS*CT92*0062) and the Netherlands Leprosy Relief Association (NSL) for their support.

\section{References}

${ }^{1}$ World Health Organization. Progress towards the elimination of leprosy as a public health problem. Weekly Epidemiol Rec 1996; 71: 149-56.

2 Klatser PR, van Beers S, Madjid B, Day R, de Wit MYL. Detection of M ycobacterium leprae nasal carriage in a leprosy endemic population. J Clin Microbiol 1993; 31: 2947-51.

${ }^{3}$ Hatta H, van Beers SM, Madjid B, de Wit MYL, Klatser PR. Distribution and persistence of Mycobacterium leprae nasal carriage among a population in which leprosy is endemic in Indonesia. Trans $R$ Soc Trop Med Hyg 1995; 89: 381-5.

4 Pallen MJ, McDermott RD. How might Mycobacterium leprae enter the body? Lepr Rev 1986; 57: $289-98$.

${ }^{5}$ Cree IA, Sharpe S, Sturrock NDC, et al. Mucosal immunity to mycobacteria in leprosy patients and their contacts. Lepr Rev 1988; 59: 309-16.

6 Ramaprasad P, Cree IA, Oluwole M, Samson PD. Development of a mucosal challenge test for leprosy using leprosin A. J Immunol Methods 1995; 188: 239-46.

7 Cree IA, Smith WCS, Beck JS. Serum antibody responses to mycobacteria in leprosy patients and their contacts.Lepr Rev 1988; 59: 317-328.

8 de Wit MYL, Douglas JT, McFadden J, Klatser PR. Polymerase chain reaction for detection of Mycobacterium leprae in nasal swab specimens. J Clin Microbiol 1993; 31: 502-6.

9 Bothamley GH, Cree IA. Antibody (IgA) specificity in leprosy. In: Advances in Mucosal Immunology (Proceedings of the Vth International Congress of Mucosal Immunology 1989), eds. MacDonald TT, Challacombe SJ, Bland PW, Stokes CR, Heatley RV, Mowat AMcI, Kluwer Academic Publishers, Dordrecht, Netherlands, 1990, pp. 493-494.

10 Bagshawe A, de-Burgh S, Fung SC, Chuah J, Berry G. The epidemiology of leprosy in a high prevalence village in Papua New Guinea. Trans R Soc Trop Med Hyg 1989; 83: $121-7$.

11 Dockrell HM, Eastcott H, Young S, MacFarlane A, Hussain R, Waters MF. Possible transmission of Mycobacterium leprae in a group of UK leprosy contacts. Lancet 1991; 338: 739-43.

12 Roche PW, Britton WJ, Failbus SS, Neupane KD, Theuvenet WJ. Serological monitoring of the response to chemotherapy in leprosy patients. Int J Lepr 1993; 61: 35-43.

${ }^{13}$ Chan GP, Garcia-Ignacio BY, Chavez VE, Livelo JB, Jimenez CL, Parrilla ML, Franzblau SG. Clinical trial of clarithromycin for lepromatous leprosy. Antimicrob Agents Chemother 1994; 38: 515-7.

14 Douglas JT, Hirsch DS, Fajardo TT, Cellona RV, Abalos RM, de la Cruz EC, Madarang MG, de Wit MY, Klatser PR. Evaluation of Mycobacterium leprae antigens in the serological monitoring of a clofaziminebased chemotherapeutic study of dapsone resistant lepromatous leprosy patients in Cebu, Philippines. Lepr Rev 1989; 60: 8-19. 
15 Pedley JC. The nasal mucus in leprosy. Lepr Rev 1973; 44: 33-5.

16 Khoo KH, Dell A, Morris-HR, Brennan PJ, Chatter jee D. Inositol phosphate capping of the nonreducing termini of lipoarabinomannan from rapidly growing strains of Mycobacterium. J Biol Chem 1995; 270: 12380-9.

17 van Beers SM, Izumi S, Madjid B, Maeda Y, Day R, Klatser PR. An epidemiological study of leprosy infection by serology and polymerase chain reaction. Int J Lepr 1994; 62: 1-9.

18 Chanteau S, Glaziou P, Plichart C, Luquiaud P, Plichart R, Faucher JF, Cartel JL. Low predictive value of PGL-I serology for the early diagnosis of leprosy in family contacts: results of a 10-year prospective field study in French Polynesia. Int J Lepr 1993; 61: 533-41.

19 Baumgart KW, Britton WJ, Mullins RJ, Basten A, Barnetson RS. Subclinical infection with Mycobacterium leprae-a problem for leprosy control strategies. Trans R Soc Trop Med Hyg 1993; 87: 412-5. 